Original Article

\title{
Use of Descriptor Codes in Agro-Morphological Characterization: Qualitative assessment of 20 Land Races of Rice (Oryza sativa L.) from West Bengal
}

\author{
Mitu De*, \\ Associate Professor, Department of Botany, Gurudas College, Kolkata 700054, West Bengal, India \\ ${ }^{*}$ Correspondence E-mail :mitude@,rediffmail.com
}

\begin{abstract}
Rice is one of the very few crop species endowed with rich genetic diversity which is embodied in the traditional rice landraces or folk varieties. It is one of the most researched crops. Rice genetic resources and human welfare are intricately interlinked. Rice has shaped the history, culture, diet and economy of billions of people of Asia. The diversity data generated in time and space have been valuable to communities, scientists and policy managers to formulate and implement conservation strategies of in situ, on-farm as well as ex situ conservation and management of genetic resources. West Bengal has rich rice genetic wealth. But this genetic wealth is being silently depleted due to the onslaught of the high-yielding varieties (HYVs) and neglect. Descriptor codes were used for the qualitative evaluation of genetic diversity among the 20 rice genotypes collected from different parts of West Bengal, following the Standard Evaluation System (SES) for rice developed by the International Rice Research Institute (IRRI). There is an urgent need to document, characterize and conserve these varieties.
\end{abstract}

Keywords: Rice landraces, descriptor codes, qualitative characterization, SES, genetic diversity

\section{Introduction}

Rice is one of the very few crop species endowed with rich genetic diversity which account over 100,000 folk varieties or landraces. It is one of the most researched crops. Rice (Oryza sativa L.) is one of the most important food crops grown worldwide and is the staple food for half of the world population (Sasaki \& Burr 2000). Rice genetic diversity has attracted great interest of researchers due to the importance of rice as one of the major world food crops, (Roy et al. 2016). This diversity is embodied in the traditional rice landraces or folk varieties.
Rice genetic resources and human welfare are intricately interlinked. Rice being the most important staple food in South and South-East Asia, the conservation of the rice diversity and utilization of the diversity for rice breeding is directly related to the food security of this heavily populated part of the world (Pant, 2010). Morphological evaluation is a preliminary step to estimate the variability and relationship among cultivars.

The use of agro-morphological traits is the most common approach utilized to estimate 
relationships between genotypes (Bajracharya et al., 2006). Knowledge of the agromorphological diversity within a crop and its distribution across agro-ecological zones could be of a great help in the management of its germplasm and the development of strategies for its improvement (Odjo et al., 2017). Developing minimal descriptors for characterisation and evaluation of different agri-horticultural crops is a pre-requisite for the National Database on Plant Genetic Resources (Mahajan et al., 2000). The agromorphological characterization is fundamental in order to provide information for plant breeding programs (Lin, 1991).

\section{Rice Landraces}

Landraces offer a valuable gene pool for future breeding program (Patra et al., 2003). For farmers, genetic diversity means varietal diversity, which farmers can clearly distinguish on the basis of agromorphological traits, phenological attributes, postharvest characteristics, and differential adaptive performance under abiotic and biotic stresses (De \& Dey, 2013). Landraces are the heterogeneous crop populations that humans deliberately cultivate. The amount of genetic diversity within species is essential for the survival of species and their adaptation to changing environments. (Gao, 2003). Importance of landraces or folk varieties can never be denied in agriculture system, because improvement in existing variety depends upon desirable genes which are possibly present in landraces and wild varieties only (Shiva, 1991).

\section{Biological poverty in the rice genepool}

This wealth of genetic resources as found in rice may provide the base for future progress in rice improvement in the face of shrinking resources both biological and physical (Chang, 1984). The widespread adoption of highyielding rice varieties (HYVs) has led to the biological poverty of rice germplasms, as local rice varieties are abandoned for modern varieties. (Pant, 2010). At present significant numbers of the West Bengal rice landraces are on the verge of being eroded (Deb, 2000, 2005). Plant genetic resources are among the most vulnerable of all non-renewable natural resources. Once lost, they are lost forever.

\section{Qualitative assessment using descriptor codes}

Qualitative characters are important for plant description and mainly influenced by the consumers preference, socio-economic scenario and natural selection (Hien et al., 2007). Some morphological characters could be grouped into distinct classes on the basis of each of these characteristics. Descriptive codes were used for traits that have more or less discontinuous genetic variation (e.g. Collar colour, Culm internode colour etc) or for traits whose nature of expression is not easily translated into numerical units.

\section{Objective of the investigation}

For many morphological features often more than two character states are observed. Descriptor codes are then used for qualitative assessment. Documentation and awareness of the ecological, agronomic and cultural importance of the still extant West Bengal folk rice varieties is necessary as many of the indigenous folk rice varieties are on the verge of extinction due to rampant cultivation of modern, high yielding varieties (HYVs). The aim of the present study was to characterize 20 accessions of landraces rice (Oryza sativa L.) varieties of West Bengal, based on qualitative agro-morphological descriptors.

\section{Methodology}

Plant Material: Rice germplasm used in this study consisted of 20 folk rice varieties of West Bengal collected from different districts of West Bengal. Both aromatic and non aromatic landraces were chosen. As a check a high yielding indigenous non aromatic was taken. One multiple seeded landrace was taken in the sample. These accessions were collected from different agro-climatic belts of West Bengal, studied under field conditions for two consecutive years.

The details of the rice genotypes are given in Table 1. 
Table 1. The rice genotypes used in this study: genotype name, place of adaptation/source and type of cultivar.

\begin{tabular}{|c|c|c|c|c|}
\hline $\begin{array}{c}\text { SL } \\
\text { No. }\end{array}$ & Genotypes & $\begin{array}{c}\text { Place of adaptation / } \\
\text { Source District }\end{array}$ & Origin & Type of Cultivar \\
\hline 1 & CHINIATAP & Hilli, Cooch Behar & CL, SF & A WBL \\
\hline 2 & JUGAL & Purulia & CL SF & MS WBL \\
\hline 3 & LATASAIL & Purulia & CL, SF & NA WBL \\
\hline 4 & KHIRABICHI & Purulia & CL, SF & NA WBL \\
\hline 5 & LALBADSHAHBHOG & Purulia & CL SF & NA WBL \\
\hline 6 & MANIKKALMA & Purulia & CL, SF & NA WBL \\
\hline 7 & MURGIBALAM & Bankura & CL, SF & NA WBL \\
\hline 8 & NYATA & Purulia & CL, SF & NA WBL \\
\hline 9 & PADMASAIL & Bankura & CL, SF & NA WBL \\
\hline 10 & PANCHALI & Purulia & CL SF & NA WBL \\
\hline 11 & PAAN & Bankura & CL, SF & NA WBL \\
\hline 12 & PATNAI & Purulia & CL, SF & NA WBL \\
\hline 13 & SWARNA & Bankura & CL SF & A WBL \\
\hline 14 & TIKARNADI & Purulia & CL, SF & A WBL \\
\hline 15 & RADHUNIPAGOL & Chakdah, Nadia & CL, SF & A WBL \\
\hline 16 & KATARIBHOG & Chakdah, Nadia & CL, SF & NA WBL \\
\hline 17 & BADSHAHBHOG & Chakdah, Nadia & CL, SF & NA WBL \\
\hline 18 & SWAPANDALI & Siliguri, Darjeeling & CL SF & NA WBL \\
\hline 19 & TULAIPANJA & Malda & & \\
\hline 20 & SONAJHULI & Dinhata, Coochbehar & & \\
\hline
\end{tabular}

Table 1. A WBL = Aromatic West Bengal landrace, $\mathrm{CL}=$ collection line, $\mathrm{HYV}=$ high yielding $N A=$ non-aromatic, INA = indigenous non-aromatic, MS WBL = multiple seeded West Bengal landrace, NA $\mathrm{WBL}=$ Non aromatic West Bengal landrace, SF = selffertilized.

\section{Experimental design}

The rice genotypes were grown in a randomized block design (RBD) with three replicates of 40 plants each. Seeds were sown in the seed bed on the last week of June and one healthy seedling/hill was transplanted after 30 days at a row $x$ plant spacing of $25 \mathrm{~cm}$ $x 15 \mathrm{~cm}$. Normal agronomic practices were followed.

\section{Descriptor Codes used for the qualitative assessment}

Qualitative characterization was done following the Standard Evaluation System (SES) for rice developed by the International Rice Research Institute (IRRI, 2002). Morphological characters and their respective descriptor codes used for the qualitative evaluation of genetic diversity among the 20 rice genotypes are given in Table 2. A total of 9 (nine) morphological characters which can be evaluated by descriptor codes were taken. The results are shown in table 3.

Table 2. List of Descriptor codes used for the qualitative evaluation of genetic diversity among the 20 rice genotypes.

\begin{tabular}{|c|c|c|c|c|c|c|}
\hline $\begin{array}{l}\text { SL. } \\
\text { No. }\end{array}$ & Trait & Abv. & Growth stage & Method of scoring & code & Description \\
\hline \multirow[t]{2}{*}{1} & \multirow[t]{2}{*}{ Auricle Colour } & \multirow[t]{2}{*}{$\mathbf{A C}$} & \multirow{2}{*}{$\begin{array}{l}\text { Stem elongation } \\
\text { to booting stage }\end{array}$} & \multirow[t]{2}{*}{ Ocular inspection } & 1 & Light green \\
\hline & & & & & 2 & Purple \\
\hline \multirow[t]{4}{*}{2} & \multirow{4}{*}{$\begin{array}{l}\text { Basal Leaf } \\
\text { Sheath Color }\end{array}$} & \multirow[t]{4}{*}{ BLSC } & \multirow{4}{*}{$\begin{array}{l}\text { Early to late } \\
\text { vegetative stage }\end{array}$} & \multirow[t]{4}{*}{ Visual observation } & 1 & Green \\
\hline & & & & & 2 & Purple lines \\
\hline & & & & & 3 & Light purple \\
\hline & & & & & 4 & Purple \\
\hline 3 & Collar Color & CC & Stem elongation & Ocular inspection. & 1 & Light Green \\
\hline
\end{tabular}




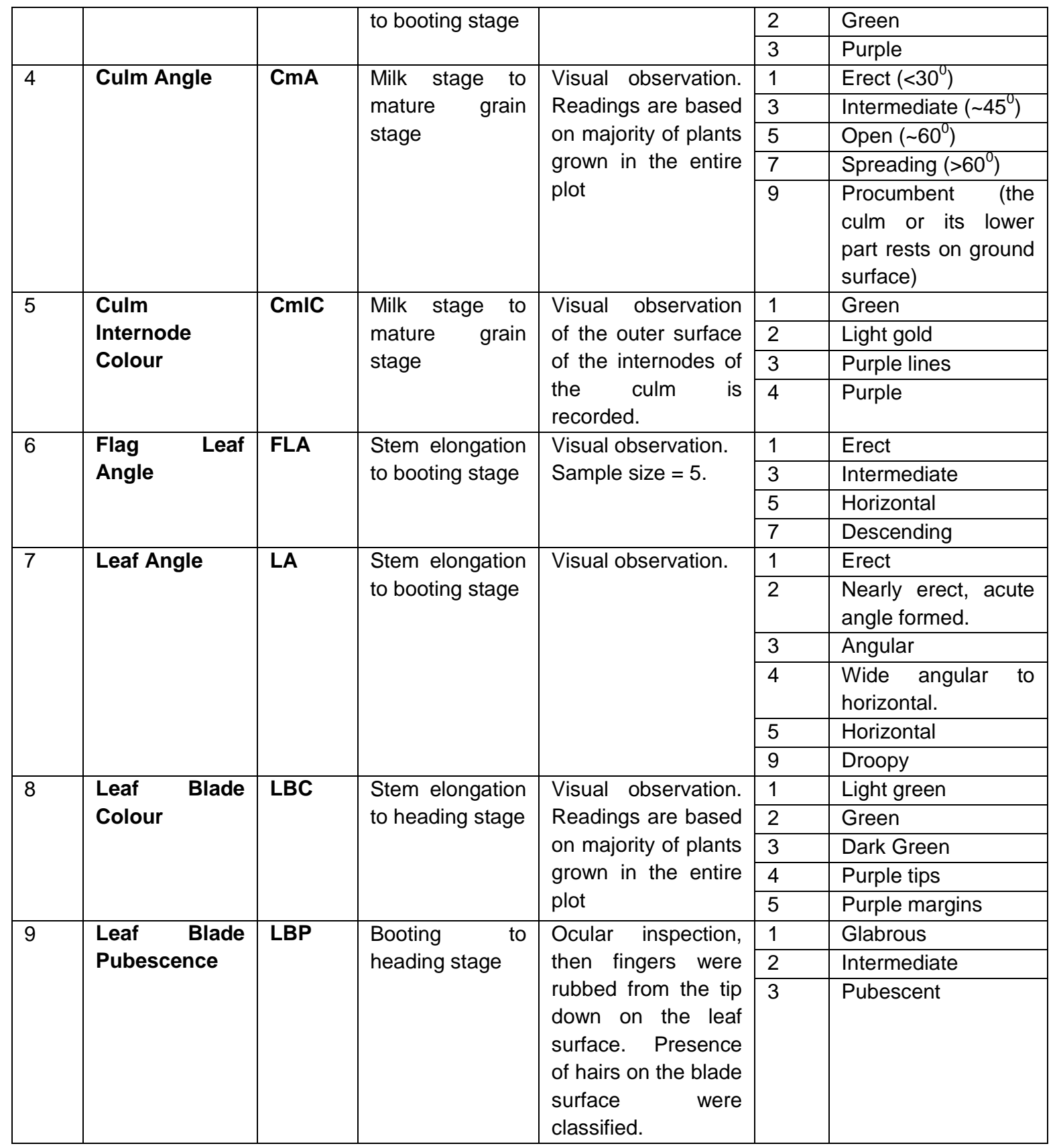

\section{Results and Discussion}

The rice genotypes selected for this study belonged to the indica group of Oryza sativa L. These rice landraces were collected from different districts of West Bengal where there are distinct eco-geographic variations. Though all the rice genotypes belonged to Oryza sativa L. the present study revealed sufficient genetic divergence for various qualitative traits (Table 3 ). This variation reflects the capability of the indigenous farmers for developing and sustaining diverse landraces.

Table 3. Qualitative evaluation: Use of descriptor codes to estimate genetic diversity among the 20 rice landraces.

\begin{tabular}{|l|l|l|l|l|l|l|l|l|l|l|}
\hline $\begin{array}{l}\text { Sl. } \\
\text { No. }\end{array}$ & Rice Land-race Name & AC & BLSC & CC & CmA & CmIC & FLA & LA & LBC & LBP \\
\hline 1 & CHINIATAP & 1 & 1 & 1 & 5 & 1 & 3 & 5 & 2 & 2 \\
\hline 2 & JUGAL & 2 & 3 & 2 & 1 & 1 & 3 & 3 & 2 & 3 \\
\hline
\end{tabular}




\begin{tabular}{|l|l|l|l|l|l|l|l|l|l|l|}
\hline 3 & LATASAIL & 2 & 4 & 3 & 3 & 2 & 5 & 5 & 2 & 3 \\
\hline 4 & KHIRABICHI & 2 & 3 & 3 & 3 & 1 & 3 & 3 & 2 & 3 \\
\hline 5 & LALBADSHAHBHOG & 1 & 1 & 1 & 1 & 2 & 5 & 5 & 2 & 3 \\
\hline 6 & MANIKKALMA & 1 & 1 & 1 & 3 & 1 & 1 & 3 & 2 & 3 \\
\hline 7 & MURGIBALAM & 1 & 1 & 2 & 3 & 1 & 1 & 3 & 2 & 3 \\
\hline 8 & NYATA & 1 & 1 & 1 & 5 & 1 & 1 & 3 & 1 & 3 \\
\hline 9 & PADMASAIL & 1 & 1 & 1 & 3 & 1 & 5 & 5 & 1 & 3 \\
\hline 10 & PANCHALI & 1 & 1 & 2 & 5 & 1 & 5 & 4 & 2 & 1 \\
\hline 11 & PAAN & 1 & 1 & 1 & 3 & 1 & 5 & 3 & 2 & 1 \\
\hline 12 & PATNAI & 1 & 1 & 1 & 1 & 1 & 1 & 3 & 2 & 3 \\
\hline 13 & SWARNA & 1 & 1 & 1 & 1 & 1 & 1 & 3 & 2 & 3 \\
\hline 14 & TIKARNADI & 1 & 1 & 1 & 5 & 1 & 1 & 3 & 7 & 3 \\
\hline 15 & RADHUNIPAGOL & 2 & 1 & 1 & 3 & 1 & 5 & 5 & 2 & 3 \\
\hline 16 & KATARIBHOG & 1 & 1 & 2 & 1 & 1 & 3 & 4 & 2 & 3 \\
\hline 17 & BADSHAHBHOG & 1 & 1 & 2 & 1 & 1 & 5 & 5 & 2 & 3 \\
\hline 18 & SWAPANDALI & 2 & 1 & 1 & 1 & 1 & 1 & 3 & 2 & 3 \\
\hline 19 & TULAIPANJA & 1 & 1 & 2 & 3 & 1 & 5 & 5 & 2 & 3 \\
\hline 20 & SONAJHULI & 1 & 1 & 1 & 1 & 1 & 1 & 3 & 2 & 3 \\
\hline
\end{tabular}

\section{Conclusion}

The basic diversity data of landraces has been found important to monitor the dynamics of crop genetic resource management. Rice (Oryza sativa L.) diversity data generated in time and space have been valuable to communities, scientists and policy managers to formulate and implement conservation strategies of in situ, on-farm as well as ex situ conservation and management of genetic resources (Li et al., 2000, Hien, 2007, De, 2014a). West Bengal has rich rice genetic wealth. But this genetic wealth is being silently depleted due to the onslaught of the highyielding varieties (HYVs) and neglect (De,

\section{References}

Bajracharya J., Steele K.A., Jarvis D.I., Sthapit B.R., Witcombe J.R. (2006). Rice landrace diversity in Nepal: Variability of agromorphological traits and SSR markers in landraces from a highaltitude site. Field Crops Research 95, pp.327-335.

Chang T. T. (1984). Conservation of rice Genetic Resources: Luxury or Necessity? Science, 224, pp. 251-256.

De, Mitu and Dey, Santi Ranjan (2013). Screening folk rice varieties of West Bengal for relative tolerance to angoumois grain moth, Sitotroga cerealella (Olivier) (Lepidoptera: Gelechiidae) and identification of factors contributing to the tolerance. J. Environ. \& Sociobiol. 10(2), pp. 201-212.

De, Mitu (2014a). Morphometric and Genetic Diversity of Folk Rice Varieties of West Bengal. J. Environ. \& Sociobiol. 11(2) pp. 163-170.

De, Mitu (2014b). Dwindling Treasures of the Rice fields of West Bengal. The Beats of Natural Sciences. 1(4), pp. 1-9.
$2014 b)$. There is an urgent need to document, characterize and conserve these varieties.

\section{Acknowledgment}

This work has been carried out with the financial assistance of the Minor Research Project of the University Grants Commission (UGC). The author gives thanks to the Director, Bose Institute, Kolkata and Dr. Tapas Kumar Ghose for providing the laboratory and experimental garden infrastructure.

Deb, D. (2000). Folk varieties of West Bengal : Agronomic and Morphological Characteristics. Navdanya / Research Foundation for Science, Technology \& Ecology. New Delhi.

Deb, D. (2005). Seeds of Tradition, Seeds of Future: Folk varieties of Eastern India. RFSTE, New Delhi.

Gao, L. (2003). The conservation of Chinese rice biodiversity: genetic erosion, ethnobotany and prospects. Genetic Resources and Crop Evolution, 50, pp.17-32.

Hien, N. L.; Sarhadi, W.A.; Hirata, Y.; Oikawa, Y. (2007). Genetic diversity of morphological responses and relationships among Asia aromatic rice (Oryza sativa L.) cultivars. Tropics 16, pp.343-355.

IRRI. (2002). Standard Evaluation System for Rice (SES). International Rice Research Institute, Los Baños, Philippines. 
Li, R.; Jiang, T.B.; Xu, C.G.; Li, X.H.; Wang, X.K. (2000). Relationship between morphological and genetic differentiation in rice (Oryza sativa L.). Euphytica 114, pp. 1-8.

Lin, M.S. (1991). Genetic base of japonica rice varieties released in Taiwan. Euphytica 56, pp. 43-46.

Mahajan, R. K., Sapra R.L., Srivastava Umesh, Singh Mahendra and Sharma G.D. (2000). Minimal Descriptors (for characterization and evaluation) of agri- horticultural crops (Part I). National Bureau of Plant Genetic Resources, New Delhi, $x i+230 p$.
Odjo, T.C., \& Dossou-Aminon, Innocent \& Dansi, Alexandre \& bonou-gbo, Zaki \& Kombaté K. (2017). AgroMorphological Characterization and Assessment of Variability within a Germplasm of Benin Rice (Oryza sativa L.) Varieties. International Journal of Current Research in Biosciences and Plant Biology. 4, pp.1-16.

Pant, K. P. (2010) More profitable rice varieties crowd beneficial landraces out. The Journal of Agriculture and Environment.11, pp 1-9. 